\title{
Pathobiology
}

Abu-Wasel, B. 182

Avci-Adali, M. 176

Farney, A.C. 194

Gellrich, N.-C. 211

Gross, G. 203

Hoffmann, A. 203

Keough, V. 182

Klinge, U. 169

Klosterhalfen, B. 169
Lindhorst, D. 211

Molinari, M. 182

Opara, E.C. 194

Pareta, R.A. 194

Park, J.-K. 169

Perle, N. 176
Renfrew, P.D. 182

Rücker, M. 211

Schlensak, C. 176

Schramm, A. 211

Schumann, P. 211

Stoll, H. 176

Vollmar, B. 167

Wagner, M.E.H. 211

Wendel, H.P. 176

Wilhelm, N. 176

\section{Subject Index Vol. 80, No. 4, 2013}

\begin{tabular}{|c|c|c|}
\hline Alginate 194 & Endothelial progenitor cells 176 & Osteosynthesis systems 211 \\
\hline Biliary stent therapy 182 & Growth factor, cell and gene therapies & Primary sclerosing cholangitis 182 \\
\hline Biomechanical properties 169 & 203 & \\
\hline Bioscaffolds 203 & & Resorbable materials 211 \\
\hline Blood-contacting materials 176 & Homing factor mimicry 176 & \\
\hline & & Surgical textile implants 169 \\
\hline Craniomaxillofacial surgery 211 & Immunoisolation 194 & \\
\hline & Islet transplantation 194 & Tendon injury 203 \\
\hline Diabetes 194 & & Tissue regeneration 203 \\
\hline Dominant strictures 182 & Large-pore mesh 169 & \\
\hline
\end{tabular}

\section{KARGER}

๑ 2013 S. Karger AG, Basel 